their demanding vocation they are themselves professional survivors. Dieter Plage lived inside an active volcano in Zaire; Alan Root took his camera for a swim with the hippos-and got a hole in the leg for his trouble. It's a hazardous business, and has already cost the life of one brave camerawoman, Lee Lyon, killed by an elephant in Rwanda, and now the talented John Pearson, accidentally shot while filming in the Ngorongoro Crater last year.

All the Survival superstars are here: Boadicea, the formidable old matriarch elephant of Manyara; Casimir the gorilla, and Fred, the sandhill crane who thought he was human. And for every creature bounding across the silver screen there is inevitably a larger-than-life character behind the camera-John Buxton, for instance, who wouldn't dream of setting out on a rhino-catching safari without his dinner jacket.

A hugely enjoyable story, told with great verve and humour, and a worthy tribute to one of the most effective weapons in the armoury of fauna preservation.

BRIAN JACKMAN

\title{
Jim Corbett's India, stories selected by R.E. Hawkins. Oxford University Press, f4.95.
}

This 250-page volume is a selection of stories and extracts from Jim Corbett's five books on India, three on the hunting of maneating tigers and leopards and two on his life among the hill people of Kumaon. A most interesting introduction provides an insight into Corbett's family background and how his books came to be published. There is little one can add to the tributes that have been paid to the books: they are now regarded as classics of their kind. Those on the hunting of maneaters are unsurpassed for their excitement and suspense, while the ones on his life in the hills, with their delightful undercurrent of folk and animal lore, reflect his great love for and understanding of the hill people. All gain in effect by the simple and unaffected manner of their telling. A selection has necessarily to leave out a great deal more than it can include; to those not already acquainted with Corbett, this book will whet their appetite and lead them to the best story of all on the Talla Des maneater, when he went out on what he feared might be a fatal last test of skill and endurance. Mr Hawkins has tried, at some lengths, to dispel the suggestion that Corbett's writings were not his own. I can only say that to those truly familiar with the Indian wildlife scene, and the Kumaon Hills in particular, it never occurred either to debate the truth of his stories or that he wrote them, albeit with his sister Maggie's counsel. The late E.P. Gee who, in his time, occupied the number one spot of wildlife expert in India, in his book not only gave Corbett credit for originating the effort to conserve India's wildlife, but also vested the Kumaon Hills with immortality because of their association with him. Corbett was an extraordinary man, and this selection of his writings gives more than a glimpse of his rare qualities as a hunter and as a human being.

B. SESHADRI

\section{IUCN Publications}

The proceedings of two specialist group meetings have been published by IUCN (Morges, Switzerland): Otters, the first working meeting in Suriname, March 1977, compiled and edited by the Group Chairman, Nicole Duplaix; and Threatened Deer, the 1977 meeting, which includes a dossier (14 papers) on the planning of restoration programmes for threatened mammals with special reference to deer; 13 papers are concerned with individual endangered species. 